\title{
Early and rapid development of insulin resistance, islet dysfunction and glucose intolerance after high-fat feeding in mice overexpressing phosphodiesterase 3B
}

\author{
Helena A Walz*, Linda Härndahl*, Nils Wierup, \\ Emilia Zmuda-Trzebiatowska, Fredrik Svennelid, \\ Vincent C Manganiello ${ }^{1}$, Thorkil Ploug², Frank Sundler, \\ Eva Degerman, Bo Ahrén ${ }^{3}$ and Lena Stenson Holst
}

Department of Experimental Medical Science, Biomedical Centre, C11, Lund University, SE-221 84 Lund, Sweden

${ }^{1}$ Pulmonary/Critical-Care Medicine Branch, NHLBI, National Institutes of Health, Bethesda, Maryland 20892, USA

${ }^{2}$ Department of Medical Physiology, the Panum Institute, DK-2200 Copenhagen, Denmark

${ }^{3}$ Department of Clinical Sciences, Lund, Biomedical Centre, B11, Lund University, SE-221 84 Lund, Sweden

(Requests for offprints should be addressed to H A Walz; Email: helena.walz@med.lu.se)

*(H A Walz and L Härndahl contributed equally to this work)

(L Härndahl is now at AstraZeneca, 3S36A Mereside, Alderly Park, Macclesfield, Cheshire, SK10 4TG, UK)

\begin{abstract}
Inadequate islet adaptation to insulin resistance leads to glucose intolerance and type 2 diabetes. Here we investigate whether $\beta$-cell cAMP is crucial for islet adaptation and prevention of glucose intolerance in mice. Mice with a $\beta$-cell-specific, 2-fold overexpression of the cAMPdegrading enzyme phosphodiesterase 3B (RIP-PDE3B/2 mice) were metabolically challenged with a high-fat diet. We found that RIP-PDE3B/2 mice early and rapidly develop glucose intolerance and insulin resistance, as compared with wild-type littermates, after 2 months of high-fat feeding. This was evident from advanced fasting hyperinsulinemia and early development of hyperglycemia, in spite of hyperinsulinemia, as well as impaired capacity of insulin to suppress plasma glucose in an insulin tolerance test. In vitro analyses of insulin-stimulated lipogenesis in adipocytes and glucose uptake in skeletal muscle
\end{abstract}

did not reveal reduced insulin sensitivity in these tissues. Significant steatosis was noted in livers from high-fat-fed wild-type and RIP-PDE3B/2 mice and liver triacylglycerol content was 3 -fold higher than in wild-type mice fed a control diet. Histochemical analysis revealed severe islet perturbations, such as centrally located $\alpha$-cells and reduced immunostaining for insulin and GLUT2 in islets from RIP-PDE3B/2 mice. Additionally, in vitro experiments revealed that the insulin secretory response to glucagon-like peptide-1 stimulation was markedly reduced in islets from high-fat-fed RIP-PDE3B/2 mice. We conclude that accurate regulation of $\beta$-cell cAMP is necessary for adequate islet adaptation to a perturbed metabolic environment and protective for the development of glucose intolerance and insulin resistance.

Journal of Endocrinology (2006) 189, 629-641

\section{Introduction}

Intracellular cAMP is crucial for pancreatic $\beta$-cell function. Insulin secretion stimulated by glucagon and incretin hormones, e.g. glucagon-like peptide-1 (GLP-1), is exerted via increased cAMP (Gromada et al. 1998). cAMP is also important for insulin biosynthesis, $\beta$-cell growth and survival (Skoglund et al. 2000, Trumper et al. 2001, Ding et al. 2003, Hui et al. 2003) and acts via both protein kinase A (PKA)-dependent and exchange protein activated by cAMP 2 (Epac2)-dependent signaling pathways (Renström et al. 1997, Ozaki et al. 2000).
The intracellular level of cAMP is regulated through the balancing activities of adenylate cyclases and cyclic nucleotide phosphodiesterases (PDEs) that hydrolyze cAMP to 5'-AMP. PDEs comprise a superfamily of enzymes (PDEs 1-11; Francis et al. 2001) that differ with regard to structure, localization, regulation and sensitivity to selective inhibitors. PDEs are believed to be important for the generation of intracellular cAMP pools, thus contributing to compartmentalization of cAMP-generated signals (Manganiello \& Degerman 1999, Mehats et al. 2002).

In pancreatic $\beta$-cells, activities of PDE1, PDE3 and PDE4 enzymes have been reported (Parker et al. 1995, 
Shafiee-Nick et al. 1995, Han et al. 1999). An important role of the PDE3B isoform in regulating insulin secretion has been inferred from studies demonstrating that inhibitors selective for PDE3 increase insulin secretion in mice (Parker et al. 1997) as well as in human and rat islets (ElMetwally et al. 1997, Ahmad et al. 2000). Furthermore, overexpression of PDE3B in clonal $\beta$-cells and rat islets has been shown to reduce cAMP and the insulinotropic response to glucose and GLP-1 (Härndahl et al. 2002). We recently described that a $7-10$-fold increase in PDE3 activity in transgenic mice (RIP-PDE3B/7 mice) results in severely disrupted islet structure, impaired first-phase insulin secretion and glucose intolerance (Härndahl et al. 2004). Another mouse line with lower, 2-3-fold overexpression (RIP-PDE3B/2) exhibits less severe features. However, they display reduced glucose-stimulated insulin secretion concomitant with islet perturbations. These data show that even a moderate overexpression of $\beta$-cell PDE3B impairs insulin secretion (Härndahl et al. 2004).

Increased insulin secretion is a prerequisite for preserving glucose tolerance during insulin resistance and it is because of defective islet adaptation that glucose intolerance develops in type 2 diabetes (Ahrén \& Pacini 2005). The mechanism responsible for islet adaptation has not been fully established. In this study we used the RIP$\mathrm{PDE} 3 \mathrm{~B} / 2$ mice to explore whether cAMP is crucial for islet adaptation and prevention of glucose intolerance. We hypothesized that RIP-PDE3B/2 mice have increased sensitivity to environmental diabetogenic factors. To induce insulin resistance we employed the model of high-fat feeding (Winzell \& Ahrén 2004) to demonstrate that islet dysfunction, glucose intolerance and insulin resistance are more severe and develop more rapidly in RIP-PDE3B/2 mice than in wild-type mice. Our data suggest also that slightly perturbed regulation of cAMP in $\beta$-cells enhances diet-induced development of diabetes; $\beta$-cell cAMP may therefore be involved in prevention of this type of diabetes.

\section{Materials and Methods}

\section{Experimental animals}

The generation and partial phenotyping of RIP-PDE3B/2 mice has previously been reported (Härndahl et al. 2004). In short, a FLAG-epitope-equipped cDNA for mouse PDE3B (Shakur et al. 2000) was placed under the control of the rat insulin promoter (RIP) 2 and microinjected into pronuclei of $\mathrm{C} 57 \mathrm{Bl} / 6 \mathrm{x} \mathrm{CBA}$ mice. Islets from RIP-PDE3B mice exhibit reduced insulin secretion.

In the present work, male RIP-PDE3B/2 mice were used in two separate studies starting at 4 (study I) and 8 (study II) weeks of age, respectively. Male mice were used because previous observations indicate a gender difference with a more advanced phenotype in the male gender (Härndahl et al. 2004). Mice were fed a diet with either
$11 \%$ (control diet; CD) or 58\% (high-fat diet; HFD) fat, calculated as the energy percentage (Research Diets, New Brunswick, NJ, USA) for 18 (study I) and 28 (study II) weeks, respectively. Wild-type littermates fed either diet were used as controls. The animals were housed singly in a temperature-controlled room $\left(22{ }^{\circ} \mathrm{C}\right)$ with a ratio of $12 \mathrm{~h}$ light: $12 \mathrm{~h}$ darkness. Both studies were approved by the Animal Ethics Committee, Lund, Sweden.

\section{Baseline parameters}

Weight gain and food intake were measured weekly. Blood samples were drawn from the retrobulbar, intraorbital capillary plexus of anesthetized (described below) mice after $4 \mathrm{~h}$ of fasting and used to monitor plasma content of glucose, hormones and free fatty acids (FFAs). Insulin, glucagon and leptin levels were determined by RIAs (Linco Research, St Charles, MO, USA). Plasma glucose was determined using the Glucose (Trinder) kit from Sigma Diagnostics or glucose (oxidase) reagent from Thermo Trace (Melbourne, Australia) and non-esterified FFAs using reagents from Wako (Neuss, Germany).

\section{Body composition measurements}

Fat and soft-lean tissue mass were determined with dual-energy X-ray absorbtiometry (GE-Lunar PIXImus; Lunar Corporation, Madison, MI, USA) as described by Nagy \& Clair (2000). After a $3 \mathrm{~h}$ fast the mice were anesthetized as described below. Each animal was scanned once to obtain the sub-cranial body composition.

\section{In vivo experiments}

Mice were anesthetized with an intraperitoneal injection of midazolam (0.15 ml injection containing $0 \cdot 2 \mathrm{mg}$ dormicum/mouse (Hoffmann-La Roche, Basel, Switzerland) and a combination of $0.4 \mathrm{mg}$ fluanison/mouse and $0.02 \mathrm{mg}$ fentanyl/mouse (Hypnorm; Janssen, Beerse, Belgium)) and blood samples were taken from the retrobulbar, intraorbital capillary plexus. Intravenous glucosetolerance tests (IVGTTs) were conducted on mice fasted for $3 \mathrm{~h}$ by injection of $1 \mathrm{~g}$ D-glucose (British Drug Houses, Poole, Dorset, UK) per kg body weight in the tail vein. Blood samples were collected after 1, 5, 10, 20, 50 and $75 \mathrm{~min}$. Changes in plasma glucose (suprabasal) and insulin secretion were evaluated by calculating the area under the curve (AUC) from 0 to $75 \mathrm{~min}$.

In insulin-tolerance tests (ITTs), mice fasted for $24 \mathrm{~h}$ were injected intraperitoneally with insulin. The amount of insulin to be administered was determined in a pre-test, designed to equilibrate the plasma insulin in the mouse groups to similar levels $10 \mathrm{~min}$ post-injection. As a result of this pre-test, in the ITTs insulin was administered at 1.0 unit $/ \mathrm{kg}$ body weight to CD-fed mice of both genotypes and HFD-fed wild-type mice, whereas HFD-fed 
RIP-PDE3B/2 mice were administered 0.7 units $/ \mathrm{kg}$ body weight. Blood samples were collected at 10, 15, 20, $25,30,35,40,45$ and $60 \mathrm{~min}$ after the injection of insulin. The volume load was $10 \mu \mathrm{l} / \mathrm{g}$ body weight. Samples were taken in heparinized tubes and stored on ice. Plasma was separated and stored at $-20^{\circ} \mathrm{C}$.

\section{Insulin-stimulated glucose uptake in skeletal muscle}

Glucose uptake was measured as described previously (Ihlemann et al. 1999). In short, the soleus muscle was removed by gentle dissection and incubated for up to $4 \mathrm{~h}$ at $29^{\circ} \mathrm{C}$ in Krebs-Henselite bicarbonate buffer, containing $8 \mathrm{mM}$ glucose, $1 \mathrm{mM}$ pyruvic acid and $0 \cdot 2 \%$ BSA continuously gassed with $95 \% \mathrm{O}_{2}$ and $5 \% \mathrm{CO}_{2}$. Muscles were placed in glucose-free Krebs-Henselite buffer containing $2 \mathrm{mM}$ pyruvic acid with or without $1 \mathrm{mU} / \mathrm{ml}$ insulin (Actrapid) for $30 \mathrm{~min}$. Glucose transport was measured as $\left[{ }^{3} \mathrm{H}\right] 2$-deoxy-D-glucose uptake with $\left[{ }^{14} \mathrm{C}\right] \mathrm{su}-$ crose as the extracellular marker. The isotopes and unlabeled sugars were added to yield final concentrations of $0 \cdot 81 \mu \mathrm{Ci}\left[{ }^{3} \mathrm{H}\right] 2$-deoxy-D-glucose and $0 \cdot 61 \mu \mathrm{Ci}\left[{ }^{14} \mathrm{C}\right] \mathrm{su}-$ crose per $\mathrm{ml}$ and $1 \mathrm{mM}$ unlabeled 2-deoxy-D-glucose and sucrose. After a 10-min exposure to the isotopes, muscles were immediately frozen in liquid nitrogen and stored at $-80{ }^{\circ} \mathrm{C}$.

\section{Insulin-stimulated lipogenesis in white adipocytes}

White adipocytes were obtained after a digestion (90 min) of mouse epididymal adipose tissue in a collagenase solution $(0.5 \mathrm{mg} / \mathrm{ml})$ of Krebs-Ringer buffer $(120 \mathrm{mM}$ $\mathrm{NaCl}, 5 \mathrm{mM} \mathrm{NaHCO}, 5 \mathrm{mM} \mathrm{KCl}, 1.2 \mathrm{mM} \mathrm{KH}_{2} \mathrm{PO}_{4}$, $2.5 \mathrm{mM} \mathrm{CaCl}_{2}$ and $1.2 \mathrm{mM} \mathrm{MgSO}_{4}$ ) supplemented with $25 \mathrm{mM}$ HEPES, pH 7•4, $2 \mathrm{mM}$ glucose and 2\% BSA, at $37^{\circ} \mathrm{C}$ with shaking $\left(120 \mathrm{~min}^{-1}\right)$. Lipogenesis was determined as described by Moody et al. (1974) with certain modifications. Aliquots $(1 \mathrm{ml})$ of $2 \%(\mathrm{v} / \mathrm{v})$ cell suspension in Krebs-Ringer buffer supplemented with $25 \mathrm{mM}$ HEPES, pH 7.4, 0.55 mM glucose and 3.5\% BSA were distributed into vials containing $0 \cdot 4 \mu \mathrm{Ci}\left[6-{ }^{3} \mathrm{H}\right]$ glucose (TRK 85; Amersham) and different concentrations of insulin (Novo Nordisk, Copenhagen, Denmark). Incubations were carried out for $3 \mathrm{~h}$ at $37^{\circ} \mathrm{C}$ while shaking $\left(80 \mathrm{~min}^{-1}\right)$. The reaction was stopped by addition of $8 \mathrm{ml}$ toluol-based scintillation liquid containing $0.3 \mathrm{mg} / \mathrm{ml}$ POPOP (1,4-bis [5-Phenyl-2-oxazolyl] benzene; $2,2^{\prime}$-pPhenylene-bis [5'-phenyloxazole]) and $5 \mathrm{mg} / \mathrm{ml}$ PPO (2,5-Diphenyloxazole) (Sigma). De novo lipid synthesis was determined by liquid scintillation counting of radioactivity incorporated into total cellular lipids.

\section{Triacylglycerol assay}

Liver samples, stored in liquid nitrogen until use, were homogenized 1:10 (w/v; 14-50 mg) in 0.5 M Tris, $\mathrm{pH} 7 \cdot 4$, and $1 \%$ Triton. Homogenate $(50 \mu \mathrm{l})$ was transferred into a glass tube containing $3 \mathrm{ml}$ chloroform/methanol (2:1) solution and stored in a $\mathrm{N}_{2}$ environment at $4{ }^{\circ} \mathrm{C}$ overnight. Water $(1.5 \mathrm{ml})$ was added and the tubes were centrifuged at $2100 \mathrm{~g}$ for $10 \mathrm{~min}$. After removal of the upper layer, $0.75 \mathrm{ml}$ water was added and the centrifugation was repeated. The samples were dried with $\mathrm{N}_{2}$ and resuspended in $200 \mu \mathrm{l}$ chloroform. Aliquots $(10 \mu \mathrm{l})$ were transferred into Eppendorf tubes and air-dried. Thesit Fluka (Bio Chemika, Buchs, Switzeland; $2 \mu \mathrm{l} ; 20 \%$, v/w, in chloroform) was added and the tubes were air-dried again. Water $(10 \mu \mathrm{l})$ was added and the samples were incubated at $37{ }^{\circ} \mathrm{C}$ for $10 \mathrm{~min}$. A standard curve was prepared with use of different concentrations of triolein. Triglyceride reagent (Thermo Trace; $300 \mu \mathrm{l}$ ) was added and the samples were transferred to a microtiter plate. The plate was incubated at $37^{\circ} \mathrm{C}$ for 5 min after which the absorbance was measured at $510 \mathrm{~nm}$.

\section{Insulin secretion and islet insulin content}

Isolation of pancreatic islets, analysis of insulin secretion and islet insulin content were conducted as previously described (Härndahl et al. 2004). For insulin secretion, collagenase-isolated islets were pre-incubated $(1 \mathrm{~h})$ in Krebs-Ringer bicarbonate buffer $(120 \mathrm{mM} \mathrm{NaCl}, 5 \mathrm{mM}$ $\mathrm{NaHCO}_{3}, 5 \mathrm{mM} \quad \mathrm{KCl}, \quad 1.2 \mathrm{mM} \quad \mathrm{KH}_{2} \mathrm{PO}_{4}, 2.5 \mathrm{mM}$ $\mathrm{CaCl}_{2}, 1 \cdot 2 \mathrm{mM} \mathrm{MgSO}, 0 \cdot 2 \% \mathrm{BSA}$ and $10 \mathrm{mM}$ Hepes, $\mathrm{pH} 7 \cdot 2-7 \cdot 4)$ at low $(3.3 \mathrm{mM})$ glucose. For each condition groups of three islets in eight replicates were incubated in Krebs-Ringer bicarbonate buffer containing glucose at the indicated concentrations in the presence or absence of $100 \mathrm{nM}$ GLP-1, for $1 \mathrm{~h}$ at $37^{\circ} \mathrm{C}$.

For determination of insulin content, groups of three islets in six replicates per mouse group were homogenized in acid ethanol. After centrifugation supernatants were removed and stored at $-20{ }^{\circ} \mathrm{C}$ until analyzed by radiochemistry.

\section{Immunohistochemistry and morphometry}

After 18 or 28 weeks of treatment with the respective diets, pancreases were removed and histological sections were generated for immunohistochemical analyses, as previously described (Härndahl et al. 2004). Briefly, pancreatic specimens were fixed in Stephanini's solution and rinsed thoroughly in Tyrode's solution. Sections were incubated overnight $\left(4{ }^{\circ} \mathrm{C}\right)$ with primary antibodies (insulin: product code 9003, dilution 1:2560, EuroDiagnostica, Malmö, Sweden; glucagon: code 8708, dilution 1:5120, EuroDiagnostica; GLUT-2: code AB 1342, dilution 1:640, Chemicon, Temecula, CA, USA; pancreatic duodenal homeobox-1 (PDX-1): dilution 1:2000, generous gift from Dr M German, University of California, San Francisco, CA, USA) diluted in PBS (pH 7.2) containing $0 \cdot 25 \%$ BSA and $0 \cdot 25 \%$ Triton X-100. Thereafter sections 
were rinsed in PBS with $0 \cdot 25 \%$ Triton X-100 and incubated with secondary antibodies for $1 \mathrm{~h}$ at room temperature.

Islet area was measured on digitized images of the prepared pancreatic sections above using NIH image software Image Pro Plus (Media Cybenetics Inc, Silver Spring, MD, USA). The analysis included sections from two separate levels, $1 \mathrm{~mm}$ apart, of each pancreas. Three mice were included in each group and approximately 100 islets were measured per group.

\section{Statistical analysis}

Data are quoted as means \pm S.E.M. of the indicated number of experiments or mice. Statistical significance was evaluated using Student's $t$ tests or ANOVA. When statistical significance was found with ANOVA, Student-NewmanKeul's or Dunett's post-hoc test was run to identify differences among the groups.

\section{Results}

Increased weight gain of high-fat-fed RIP-PDE3B/2 mice

To assess the metabolic effects of high-fat feeding in a setting of lowered $\beta$-cell cAMP, transgenic RIP-PDE3B/2 mice were utilized. Two separate studies were conducted, one of which (study I) included younger mice between 4 and 24 weeks of age. Study II included adult animals from 8 to 36 weeks of age. With this exception, the two studies were similarly designed; groups of 10 RIP-PDE3B/2 or wild-type control mice were fed either a CD or a HFD. The studies were designed to complement each other and hence not all parameters were investigated in both studies. When comparable, results from the two studies were very similar. However, a slight difference was evident in the body-weight development of the wild-type mice; the weight increase was slower in study I than in study II (Fig. 1). Comparing body weight development of mice on the different diets disclosed that when kept on CD, body weight increased similarly in wild-type and RIPPDE3B/2 mice (Fig. $1 \mathrm{~A}$ and B). However, upon HFD feeding, the RIP-PDE3B/2 mice gained significantly more weight than their wild-type littermates (Fig. 1A and B). To discern whether these differences represented an increase in fat tissue mass, in study I the body composition was determined after 14 weeks of dietary treatment. As expected, HFD-fed mice had significantly more body fat than mice fed CD (50 vs $30 \%$ of total body weight, $P<0 \cdot 001, n=10$; Fig. 1C). However, percentage body fat did not differ between RIP-PDE3B/2 mice and wildtype littermates fed HFD (Fig. 1C). Instead, the difference in weight between HFD-fed RIP-PDE3B/2 and wildtype mice is attributable to the sum of slightly greater lean and fat tissue in the RIP-PDE3B/2 mice. Furthermore, there were no differences in feed efficiency (i.e. weight
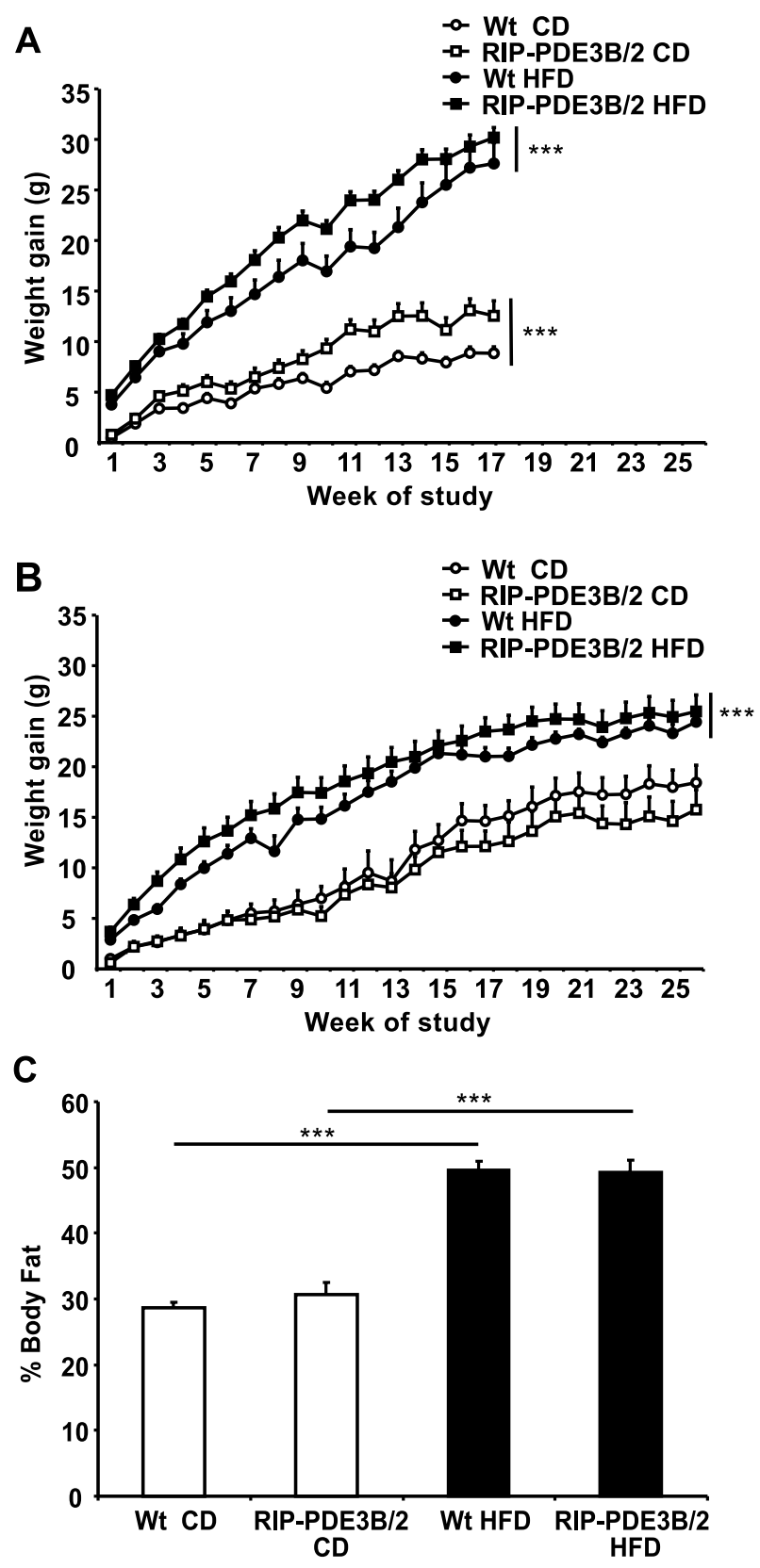

Figure 1 Weight gain (A, B) and body composition (C) of RIP-PDE3B/2 and wild-type (Wt) mice fed CD or HFD.

(A, B) Weight gain during studies I and II, respectively. Values are presented as means \pm S.E.M. $\left(n=10\right.$ mice). ${ }^{* *} P<0 \cdot 001$ comparing wild-type HFD and RIP-PDE3B/2 HFD (studies I and II) and $* * * P<0 \cdot 001$ comparing wild-type CD and RIP-PDE3B/2 CD (study l; ANOVA). (C) Body composition after 14 weeks of dietary treatment (study I). Values are presented as means \pm S.E.M. $(n=10)$, $* * * P<0 \cdot 001$ (ANOVA).

gain/calorie intake) between the RIP-PDE3B/2 and wild-type mice, indicating that the increased weight gain of RIP-PDE3B/2 mice was not caused by more efficient 
Table 1 Accumulated calorie intake (kcal) in wild-type $(\mathrm{Wt})$ and RIP-PDE3B/2 mice fed CD or HFD in study I

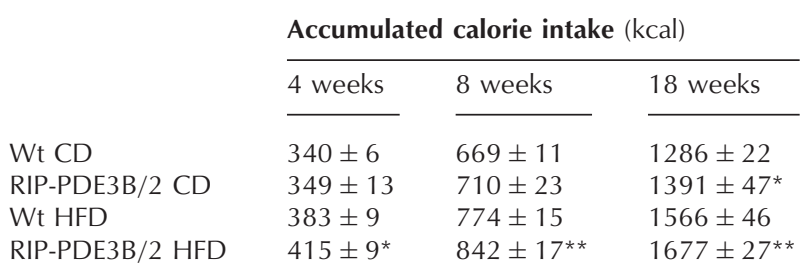

Data are means \pm S.E.M. ${ }^{*} P<0 \cdot 05$ and ${ }^{* *} P<0 \cdot 01$ (Student's $t$ test) comparing RIP-PDE3B/2 and Wt mice within each specific diet group.

storage of ingested calories. However, RIP-PDE3B/2 mice showed somewhat higher food (calorie) intake compared with wild-type mice (Table 1).

Circulating FFAs were significantly increased (by $40-50 \%)$ in $4 \mathrm{~h}$-fasted mice of all groups during the 8 first weeks of study II (Table 2). However, there were no noticeable differences in FFA levels between RIP-PDE3B/2 and wild-type mice over time. On the other hand, the adipose tissue-derived protein leptin, which is known to increase with the development of obesity, was elevated in plasma from RIP-PDE3B/2 mice fed HFD for 8 weeks compared with similarly fed wildtype mice (Table 2).

\section{High-fat-fed RIP-PDE3B/2 mice rapidly develop fasted hyperinsulinemia and hyperglycemia}

To monitor metabolic status, levels of circulating insulin and glucose (after a $4 \mathrm{~h}$ fast) were analyzed repeatedly. In wild-type and RIP-PDE3B/2 mice fed CD, plasma insulin increased 2-fold during the 18-week-long study I
(Fig. 2A). Whereas wild-type mice remained euglycemic on CD, RIP-PDE3B/2 mice displayed moderate hyperglycemia, measurable already at 4 weeks (Fig. 2B). In study II, CD-fed mice also increased plasma insulin during the course of the study (Table 2), but hyperglycemia was not as evident in the RIP-PDE3B/2 mice as in study I.

In both studies, HFD feeding rendered all mice hyperglycemic, but to different extents in wild-type and transgenic mice. In wild-type mice, the development of hyperglycemia (defined as plasma glucose $>12 \mathrm{mM}$ ) was associated with a pronounced $(\sim 5$-fold) increase in plasma insulin between weeks 8 and 18 on HFD (study I; Fig. 2A). In contrast, in RIP-PDE3B/2 mice, a large $(\sim 4$-fold $)$ increase in plasma insulin was observed between weeks 4 and 8 . This increase was further accentuated at the end of the study with values attaining the same end point as the wild-type mice (Fig. 2A). Despite the increasing insulin levels, the RIP-PDE3B/2 mice exhibited steadily elevating plasma glucose concentrations with time (Fig. 2B), indicating peripheral insulin resistance. Thus, whereas wild-type mice maintained normal fasting glucose levels by increasing plasma insulin, RIP-PDE3B/2 mice demonstrated failing glycemic regulation from halfway through the HFD feeding period. In study II, when measured at week 8 and 24 of HFD feeding, the development of plasma glucose and insulin values showed the same tendency as in study I; the increased plasma insulin levels of the RIP-PDE3B/2 mice did not suffice to counteract the elevating plasma glucose in these mice (Table 2).

Glucagon levels in plasma were analyzed in study II. At 8 weeks of HFD feeding the RIP-PDE3B/2 mice showed significantly increased fasting levels of plasma glucagon (Table 2), indicating perturbed glucose homeostasis.

Table 2 Baseline parameters of metabolic status in wild-type (Wt) and RIP-PDE3B/2 mice fed CD or HFD in study II

\begin{tabular}{|c|c|c|c|c|c|}
\hline & Leptin (ng/ml) & FFAs $(\mathrm{mM})$ & Glucose (mM) & Insulin ( $\mathrm{pM})$ & Glucagon $(\mathrm{pg} / \mathrm{ml})$ \\
\hline \multicolumn{6}{|l|}{ Start of study } \\
\hline Wt CD & $2 \cdot 2 \pm 0 \cdot 4$ & $0.82 \pm 0.09$ & $10 \cdot 8 \pm 0 \cdot 6$ & $313 \pm 59$ & $7 \cdot 3 \pm 1 \cdot 6$ \\
\hline RIP-PDE3B/2 CD & $2 \cdot 0 \pm 0 \cdot 2$ & $0 \cdot 98 \pm 0.04$ & $9 \cdot 2 \pm 0 \cdot 7$ & $216 \pm 44$ & $17 \cdot 3 \pm 4 \cdot 6$ \\
\hline Wt HFD & $1 \cdot 7 \pm 0 \cdot 1$ & $0.96 \pm 0.08$ & $11 \cdot 6 \pm 0 \cdot 7$ & $286 \pm 37$ & $8 \cdot 6 \pm 3 \cdot 0$ \\
\hline RIP-PDE3B/2 HFD & $2 \cdot 1 \pm 0 \cdot 2$ & $1 \cdot 0 \pm 0 \cdot 10$ & $9 \cdot 3 \pm 0 \cdot 6^{*}$ & $373 \pm 121$ & $11 \cdot 3 \pm 2 \cdot 2$ \\
\hline \multicolumn{6}{|l|}{8 Weeks } \\
\hline Wt CD & $5 \cdot 9 \pm 1 \cdot 5$ & $1 \cdot 31 \pm 0 \cdot 12$ & $15 \cdot 0 \pm 0 \cdot 4$ & $509 \pm 129$ & $33 \cdot 4 \pm 4 \cdot 8$ \\
\hline RIP-PDE3B/2 CD & $6 \cdot 4 \pm 0 \cdot 7$ & $1 \cdot 45 \pm 0.08$ & $10 \cdot 8 \pm 0 \cdot 6$ & $682 \pm 122$ & $39 \cdot 1 \pm 3 \cdot 5$ \\
\hline Wt HFD & $23 \cdot 0 \pm 3 \cdot 7$ & $1 \cdot 40 \pm 0.07$ & $14 \cdot 8 \pm 0 \cdot 5$ & $851 \pm 181$ & $44 \cdot 1 \pm 5 \cdot 7$ \\
\hline RIP-PDE3B/2 HFD & $34 \cdot 0 \pm 2 \cdot 7^{* *}$ & $1 \cdot 33 \pm 0 \cdot 05$ & $16 \cdot 9 \pm 1 \cdot 5$ & $1305 \pm 173^{*}$ & $61 \cdot 3 \pm 5 \cdot 1^{*}$ \\
\hline \multicolumn{6}{|l|}{24 Weeks } \\
\hline Wt CD & $22 \cdot 2 \pm 2 \cdot 0$ & $1 \cdot 35 \pm 0.08$ & $12 \cdot 1 \pm 1 \cdot 2$ & $813 \pm 179$ & $32 \cdot 7 \pm 4 \cdot 1$ \\
\hline RIP-PDE3B/2 CD & $25 \cdot 7 \pm 1 \cdot 4$ & $1 \cdot 14 \pm 0 \cdot 04$ & $14 \cdot 2 \pm 0 \cdot 9$ & $982 \pm 488^{*}$ & $54 \cdot 3 \pm 4 \cdot 0$ \\
\hline Wt HFD & $48 \cdot 9 \pm 4 \cdot 5$ & $1 \cdot 04 \pm 0 \cdot 04$ & $9 \cdot 3 \pm 0 \cdot 7$ & $1666 \pm 729$ & $54 \cdot 9 \pm 5 \cdot 5$ \\
\hline RIP-PDE3B/2 HFD & $46 \cdot 2 \pm 3 \cdot 3$ & $1 \cdot 08 \pm 0.04$ & $16 \cdot 0 \pm 1 \cdot 2^{* *}$ & $1831 \pm 389$ & $55 \cdot 6 \pm 5 \cdot 6$ \\
\hline
\end{tabular}

Data are means \pm S.E.M. ${ }^{*} P<0 \cdot 05$ and ${ }^{*} P<0 \cdot 01$ (Student's $t$ test) comparing RIP-PDE3B/2 and Wt mice within each specific diet group. 

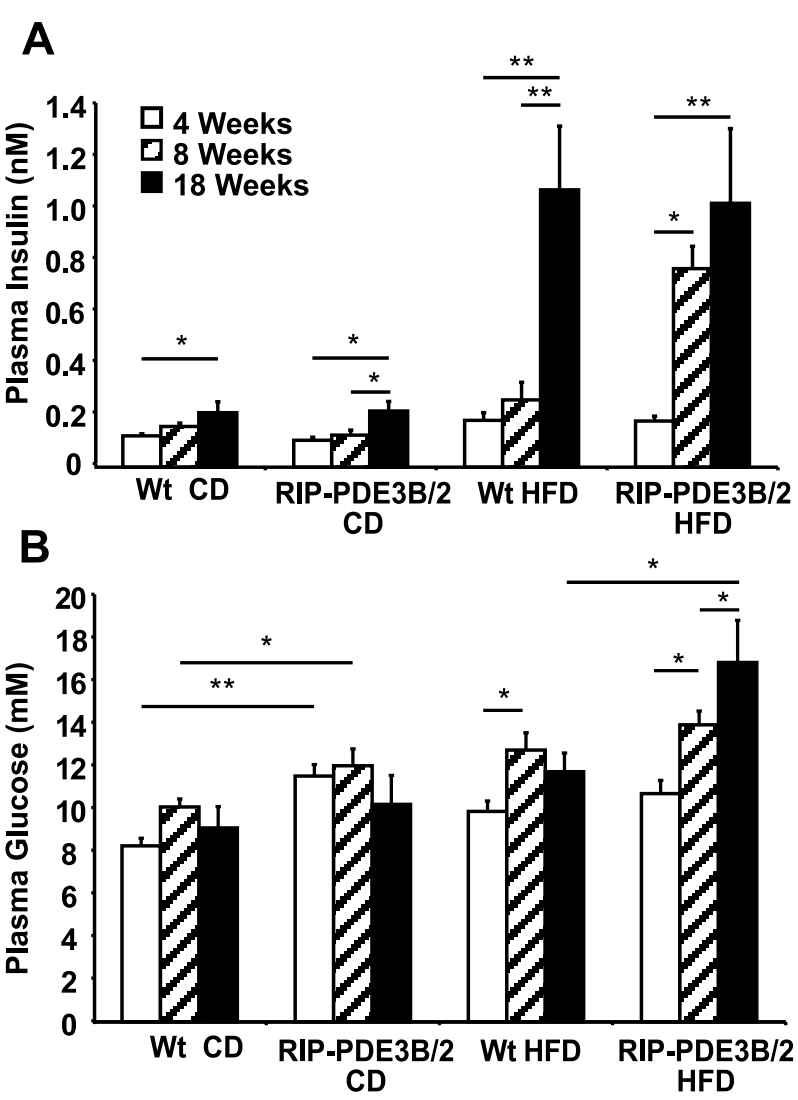

Figure 2 Plasma insulin (A) and plasma glucose (B). Blood samples were drawn after a $4 \mathrm{~h}$ fast from RIP-PDE3B/2 mice and wild-type (Wt) mice fed CD or HFD at 4, 8 and 18 weeks of dietary treatment (study I). Values are presented as means \pm S.E.M. $(n=10),{ }^{*} P<0 \cdot 05$ and ${ }^{*} P<00 \cdot 01$ (ANOVA).

High-fat-fed RIP-PDE3B/2 mice develop early and severe insulin resistance

Diet-induced hyperinsulinemia may be regarded as a compensation for a developing insulin resistance. To further study the insulin resistance of the HFD-fed mice, IVGTTs were performed after 6 and 10 weeks of dietary treatment (study II; Fig. 3). When fed CD, the acute (1 min) insulin response (AIR) to an intravenous glucose load differed between wild-type and RIP-PDE3B/2 mice, showing 280 and $200 \%$ increases, respectively, at week 6 (Fig. 3A) and 140 and 120\% increases, respectively, at week 10 (Fig. 3B). There was no significant difference in the rate of glucose elimination, but calculation of total glucose elimination $\left(\mathrm{AUC}_{\text {glucose }}\right)$ during IVGTT at week 10 revealed a significantly reduced hypoglycemic response in RIP-PDE3B/2 mice (Fig. 3D, inset).

Upon IVGTT after 6 weeks of HFD feeding, RIP$\mathrm{PDE} 3 \mathrm{~B} / 2$ mice exhibited fasting hyperinsulinemia and a 4-fold-reduced AIR compared with CD-fed RIP-PDE3B/2 mice. The AIR value of HFD-fed wild-type mice was also drastically reduced, showing a $20 \%$ increase in insulin secretion (Fig. 3A). Interestingly, after 6 weeks on the HFD, the total insulin secretion $\left(\mathrm{AUC}_{\text {insulin }}\right)$ during the IVGTT was significantly higher in RIP-PDE3B/2 mice than in wild-type mice (Fig. $3 \mathrm{~A}$, inset). This hypersecretion of insulin rendered RIP-PDE3B/2 mice capable of eliminating the glucose load to a similar extent as did wild-type mice (Fig. 3C, inset). However, after 10 weeks of HFD feeding, the ability of RIP-PDE3B/2 mice to adequately increase insulin secretion in response to the intravenous glucose load was significantly reduced. The AIR values were now lower (increasing insulin by $7 \%$ (wild-type) and 13\% (RIP-PDE3B/2)), and the $\mathrm{AUC}_{\text {insulin }}$ was reduced by $50 \%$ in RIP-PDE3B/2 mice, compared with the IVGTT results at 6 weeks of high-fat feeding (Fig. 3B). In wildtype mice, the $\mathrm{AUC}_{\text {insulin }}$ was retained at the lower level observed at 6 weeks (Fig. 3B, inset). Despite the higher $\mathrm{AUC}_{\text {insulin }}$ seen in RIP-PDE3B/2 mice, their glucose eliminatory capacity was reduced (Fig. 3D).

ITTs were performed to further study the insulin resistance in HFD-fed RIP-PDE3B/2 mice (study I). Because of the noted hyperinsulinemia in RIP-PDE3B/2 mice fed HFD, a smaller amount of insulin was needed to attain plasma levels of insulin comparable to those in plasma from wild-type and CD-fed mice. Therefore, in a pre-test different amounts of insulin were administered intraperitoneally to the mice and plasma insulin concentrations were measured 10 min post-injection. Based on the results from this pre-test, the insulin administered in the ITTs was 1.0 unit/ $\mathrm{kg}$ body weight to CD-fed mice of both genotypes and HFD-fed wild-type mice, whereas HFD-fed RIP-PDE3B $/ 2$ mice were given 0.7 units $/ \mathrm{kg}$ body weight. Plasma insulin levels were monitored throughout the ITT and proved to be similar in mice fed the same diet $(0 \cdot 20-0 \cdot 25 \mathrm{nM}(\mathrm{CD})$ and $0 \cdot 55-0 \cdot 70 \mathrm{nM}$ (HFD)). Monitoring plasma glucose for $1 \mathrm{~h}$ post-injection of insulin at the above prerequisites disclosed strongly impaired glucose elimination in RIP-PDE3B/2 mice at 10 weeks of HFD treatment (study I; Fig. 4). HFD-fed RIP-PDE3B/2 mice showed a dramatically reduced glucose-elimination rate in comparison with both HFDfed wild-type mice $(0.04 \pm 0.02$ versus $0.18 \pm 0.02 \mathrm{mM} /$ $30 \mathrm{~min}, \quad P<0 \cdot 001, n=10)$ and CD-fed RIP-PDE3B $/ 2$ mice $(0 \cdot 11 \pm 0 \cdot 01 \mathrm{mM} / 30 \mathrm{~min}, P<0 \cdot 01, n=10)$. Similar results were obtained in study II, employing an ITT after 26 weeks of HFD feeding (data not shown).

Because of the rapidly evolving insulin resistance in RIP-PDE3B/2 mice fed HFD we were interested in looking for possible disruptions in signaling pathways in insulin-sensitive tissues. Therefore, we performed several end-point analyses in vitro (study I), including insulinstimulated glucose uptake in skeletal muscle. To this end, soleus muscles were excised and uptake of $\left[{ }^{3} \mathrm{H}\right] 2$-deoxyD-glucose was measured in the presence or absence of insulin. The results revealed a 3-6-fold increase in glucose 

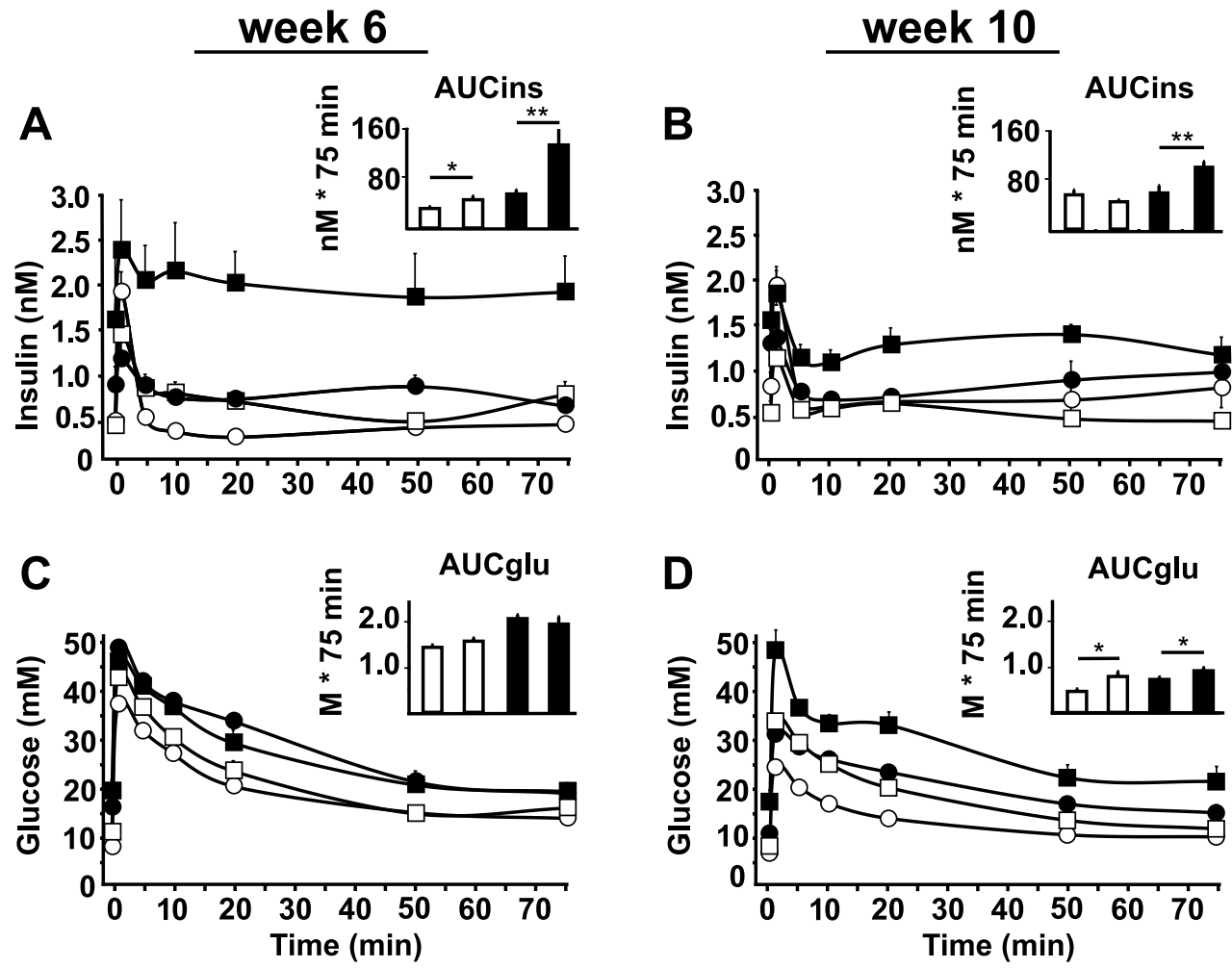

Figure 3 IVGTTs in RIP-PDE3B/2 and wild-type (Wt) mice performed after 6 (A and C) and 10 (B and D) weeks on CD or HFD (study II). $\bigcirc$, Wild-type CD; $\square$, RIP-PDE3B/2 CD; $\bullet$, wild-type HFD; $\mathbf{\square}$, RIP-PDE3B/2 HFD. Blood samples were drawn after a $3 \mathrm{~h}$ fast, before and after an intravenous injection of glucose $(1 \mathrm{~g} / \mathrm{kg})$, and plasma insulin $(A$ and $B)$ and glucose $(C$ and $D)$ levels at the indicated time points were determined. Values are presented as means \pm S.E.M. $(n=10)$. The insets show $\mathrm{AUC}_{\text {insulin }}(\mathrm{A}$ and $\mathrm{B})$ or $A \cup C_{\text {ese }}(C$ and $D)$ for the 75 min of the IVGTTs. In order from the left, the bars in each inset represent wild-type CD, RIP-PDE3B/2 CD, wild-type HFD and RIP-PDE3B/2 HFD. Data are presented as means \pm S.E.M. $(n=10),{ }^{*} P<0 \cdot 05$ and ${ }^{* *} P<0 \cdot 01$ (Student's $t$ test).

transport upon stimulation with $1 \mathrm{mU} / \mathrm{ml}$ insulin. However, there were no statistically significant differences between the four groups of mice $(n=6$; Fig. $5 \mathrm{~A})$.

Insulin-stimulated adipocyte lipogenesis was also measured (study I). As shown in Fig. 5B, adipocytes isolated from RIP-PDE3B/2 and wild-type mice appeared equally sensitive to insulin, irrespective of dietary treatment. On the other hand, insulin-stimulated lipogenesis was significantly reduced in adipocytes from mice on the HFD as compared with adipocytes from CD-fed mice (Fig. 5B, $P<0 \cdot 05, n=3$ ).

Steatosis of the liver is associated with hepatic insulin resistance (Seppala-Lindroos et al. 2002). We therefore decided to measure the extent of steatosis by quantifying triacylglycerol in the liver. As expected, HFD feeding of wild-type mice resulted in a significant increase $(\sim 2 \cdot 4-$ fold, $P<0 \cdot 001, n=3)$ in accumulated liver triacylglycerol as compared with CD-fed wild-type mice (Fig. 5C). More surprising was that CD-fed RIP-PDE3B/2 mice showed an extensive accumulation of triacylglycerol, a $\sim 3 \cdot 5$-fold increase, $(P<0 \cdot 001, n=3)$ in comparison to their CD-fed wild-type littermates (Fig. 5C). This increase in liver triacylglycerol in RIP-PDE3B/2 mice was not further augmented with HFD feeding (Fig. 5C). Notwithstanding, when fed HFD RIP-PDE3B/2 mice showed a significant increase $(\sim 48 \%, P<0 \cdot 05, n=3)$ in stored liver triacylglycerol over their wild-type littermates fed the same diet (Fig. 5C).

Islets from RIP-PDE3B/2 mice exhibit impaired glucose-stimulated insulin secretion

As an end point of study I, the islet secretory capacities of the mice were examined in static incubations. Groups of 


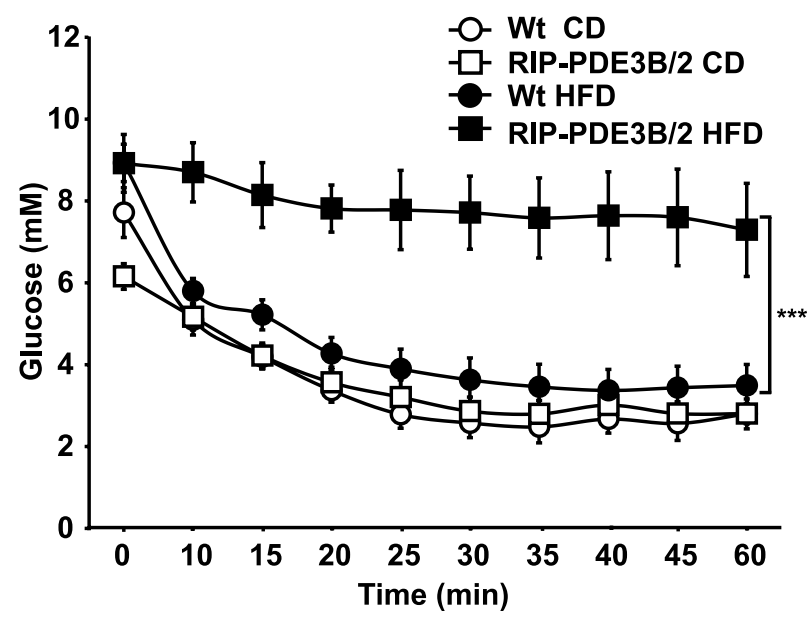

Figure 4 Intraperitoneal ITTs in RIP-PDE3B/2 and wild-type (Wt) mice fed CD or HFD after 10 weeks of dietary treatment (study I). Blood samples were drawn after a $24 \mathrm{~h}$ fast, before and after an intraperitoneal injection of insulin. Plasma glucose was determined at the indicated time points. Values are presented as means \pm S.E.M. $(n=10),{ }^{* *} P<0 \cdot 001$ (ANOVA).

three freshly isolated and randomly hand-picked islets were analyzed in eight replicates per condition. Basal insulin secretion at $3.3 \mathrm{mM}$ glucose as well as insulin secretion stimulated by $16.7 \mathrm{mM}$ glucose, in the absence or presence of $100 \mathrm{nM}$ GLP-1, was augmented in islets from HFD-fed mice compared with islets from CD-fed mice, irrespective of genotype $(P<0 \cdot 001$; Fig. 6). However, when comparing the two genotypes, the secretory response to glucose was significantly reduced in islets from HFD-fed RIP-PDE3B/2 mice compared with the wildtype $(9 \cdot 4 \pm 2 \cdot 0$ vs $15 \cdot 3 \pm 2 \cdot 0 \mathrm{ng}$ insulin/ 3 islets per $\mathrm{h}$, $P<0 \cdot 05, n=24)$. Likewise, the ability to respond to GLP-1 $(100 \mathrm{nM})$ was markedly reduced in islets of HFD-fed RIP-PDE3B/2 mice $(15 \cdot 2 \pm 2 \cdot 5$ (RIP-PDE3B/2) vs $31 \cdot 5 \pm 4 \cdot 7$ (wild-type) ng insulin $/ 3$ islets per $\mathrm{h}, P<0 \cdot 01$, $n=24$; Fig. 6).

\section{Altered islet cell topography in RIP-PDE3B/2 mice fed HFD}

Pancreatic sections of mice at the age of 22 weeks (the end of study I) were prepared for morphometric and immunohistochemical analyses. Comparative morphometric measurements of islet size revealed that there were no significant differences between the four groups of mice (average islet size between the groups ranging from $10.7 \times 10^{3} \pm 1.3 \times 10^{3}$ to $12.5 \times 10^{3} \pm 1.6 \times 10^{3}{\mu \mathrm{m}^{2}}^{2}$. This contradicts morphometric data in a previous paper by us where we reported a doubling of islet size in RIP-PDE3B/2 mice compared with islets of wild-type mice (Härndahl et al. 2004). However, these mice were older ( $\sim 9$ months) when studied in this regard.

Insulin staining of pancreatic sections revealed a generally high, but unevenly distributed insulin signal and some
A

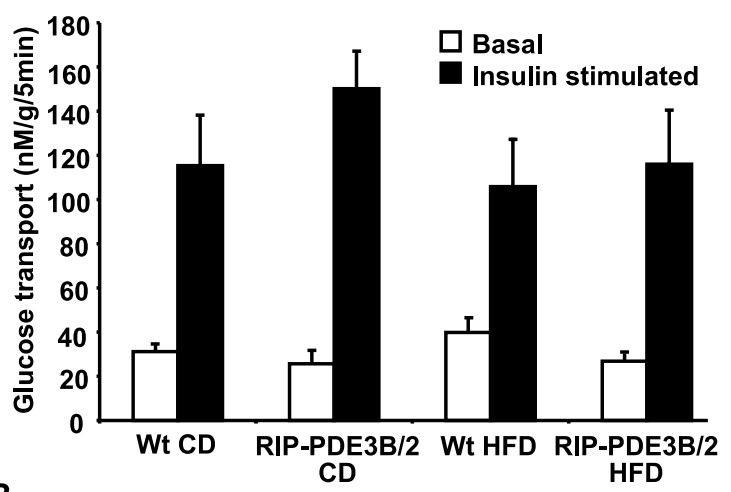

B

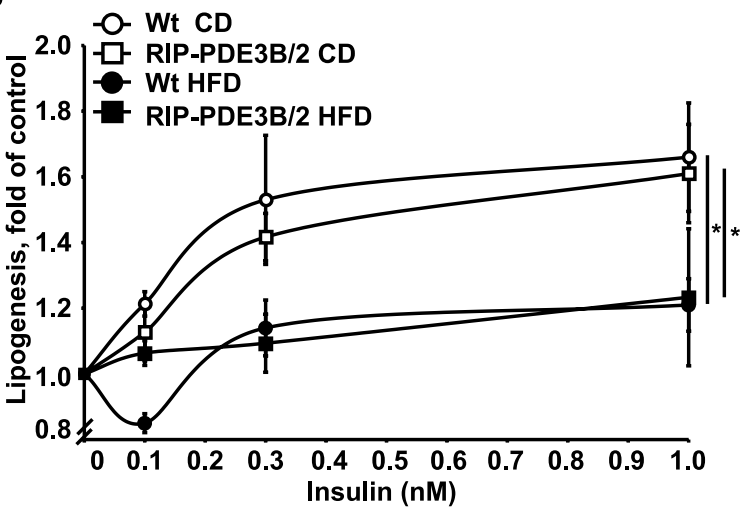

C

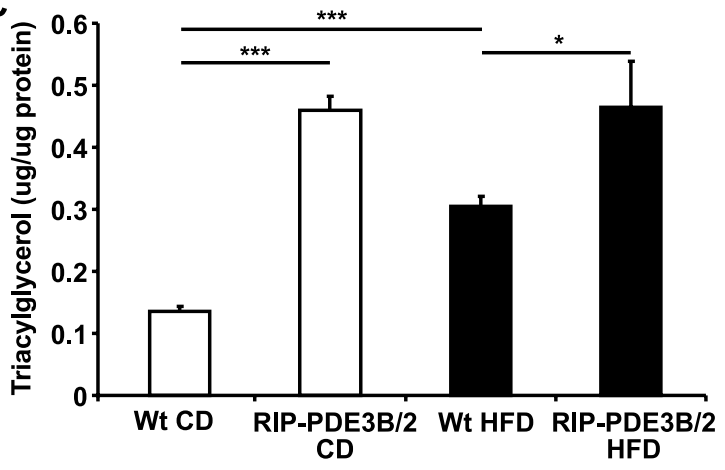

Figure 5 Insulin-induced effects in skeletal muscle (A), adipose tissue (B) and triacylglycerol content in liver (C) from RIP-PDE3B/2 and wild-type $(\mathrm{Wt})$ mice fed either $\mathrm{CD}$ or HFD for 18 weeks (study I). (A) Insulin-stimulated glucose uptake in soleus muscle. Soleus muscles were pre-stimulated with $1 \mathrm{mU}$ insulin/ml for $30 \mathrm{~min}$ and glucose uptake was measured for $10 \mathrm{~min}$. Data are presented as means \pm S.E.M. $(n=6)$. (B) Adipocytes were stimulated with insulin at the indicated concentrations for $3 \mathrm{~h}$ and lipogenesis was determined. Data are presented as the fold increase as compared with unstimulated cells in each group. Values are the means \pm S.E.M. $(n=3),{ }^{*} P<0 \cdot 05$ comparing the genotypes, respectively (ANOVA). (C) Liver homogenates analyzed for triacylglycerol content. Values are the means \pm S.E.M. $(n=3 ; 1-3$ mice in each group), ${ }^{*} P<0 \cdot 05$ and ${ }^{* *} P<0 \cdot 001$ (ANOVA).

areas with either markedly reduced or undetectable staining in islets from RIP-PDE3B/2 mice fed CD (Fig. 7B). 


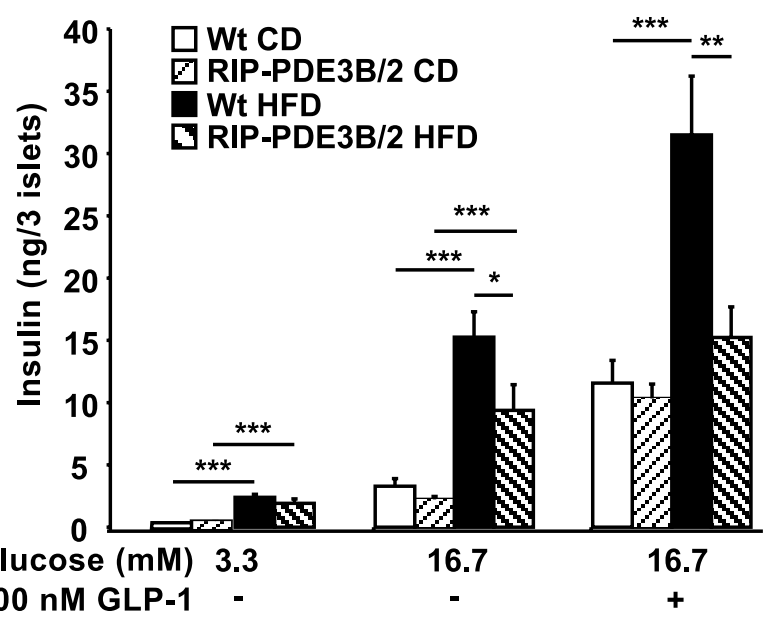

Figure 6 Glucose-stimulated insulin secretion in vitro (study I). At 22 weeks of age and after 18 weeks of feeding isolated islets from RIP-PDE3B/2 and wild-type (Wt) mice fed either CD or HFD were pre-incubated $(1 \mathrm{~h})$ in $3 \mathrm{mM}$ glucose. For each condition, groups of three islets in eight replicates were then further incubated $(1 \mathrm{~h})$ in glucose at the indicated concentrations, in the presence or absence of GLP-1, and the accumulated amount of insulin was determined. Values are presented as means \pm S.E.M. $(n=24)$, ${ }^{*} P<0 \cdot 05,{ }^{*} P<0 \cdot 01$ and ${ }^{* *} P<0 \cdot 001$ (ANOVA).

HFD treatment of RIP-PDE3B/2 mice resulted in more severe impairment of insulin staining with even larger areas lacking a detectable signal (Fig. 7D). Also, in wild-type mice fed HFD, the insulin staining pattern was weakened and more unevenly distributed (Fig. 7C). In accordance, analyses of insulin content in islets revealed $\sim 40 \%$ less insulin in CD-fed RIP-PDE3B/2 islets compared with wild-type islets, after normalizing for total protein $(1 \cdot 7 \pm 0 \cdot 3$ versus $2 \cdot 9 \pm 0 \cdot 3 \mathrm{ng}$ insulin $/ \mu \mathrm{g}$ total protein, $P<0 \cdot 01, n=18$; Fig. $7 \mathrm{M}$ ). A further reduction was noted in islets of both RIP-PDE3B/2 and wild-type mice fed HFD $(0 \cdot 9 \pm 0 \cdot 1$ and $1 \cdot 0 \pm 0 \cdot 1 \mathrm{ng}$ insulin/ $\mu \mathrm{g}$ total protein).

As a sign of altered islet cell topography, centrally located $\alpha$-cells were regularly seen in wild-type mice fed HFD and RIP-PDE3B/2 mice fed CD (Fig. 7C and B). In RIP-PDE3B/2 mice fed HFD this was more pronounced; centrally located $\alpha$-cells were present in the majority of the islets (Fig. 7D).

Staining for GLUT2 was robust in islets from wild-type mice fed CD and demonstrated the expected $\beta$-cell plasma membrane location (Fig. 7E). In islets from wild-type mice fed HFD, as well as islets from RIP-PDE3B/2 mice on CD, the GLUT2 immunostaining was markedly impaired showing both weaker membrane staining and irregular intra-islet distribution with areas lacking detectable GLUT2 (Fig. 7F and G). In RIP-PDE3B/2 mice challenged with HFD the vast majority of the $\beta$-cells were abnormal, in that there was virtually no membrane staining of GLUT2 (Fig. 7H).
There was no difference in the pattern of PDX-1 immunostaining between the two genotypes. Notably, the intensity of PDX-1 immunostaining was somewhat enhanced in the $\beta$-cell nuclei in both genotypes fed HFD compared with those fed CD (Fig. 7I-L). Morphological experiments performed on pancreatic specimens from the 36 week old mice of study II revealed similar, but even more pronounced, deterioration of islet architecture in the HFD-fed RIP-PDE3B/2 mice (data not shown).

\section{Discussion}

In this work we examined the hypothesis that $\beta$-cell cAMP is protective for the development of glucose intolerance in the setting of reduced insulin sensitivity. We used a mouse model that exhibits modest, 2-fold overexpression of the cAMP-degenerating enzyme PDE3B in $\beta$-cells. Previous control experiments, conducted by us (Härndahl et al. 2002), demonstrate the direct effect of overexpression of PDE3B on the reduction of cAMP levels. This has been confirmed through measurements of cAMP and the use of specific PDE3 inhibitors. The major finding in this work is the early and striking appearance of hyperglycemia, islet dysfunction, glucose intolerance and insulin resistance in RIP-PDE3B/2 mice that are fed a HFD. As was observed both previously (Härndahl et al. 2004) and in the present study, standarddiet-fed RIP-PDE3B/2 mice exhibit a deficient insulinotropic response to glucose and the cAMP-elevating hormone GLP-1. In addition, islets from RIP-PDE3B/2 mice exhibit reduced immunostaining of insulin and GLUT2 as well as centrally located $\alpha$-cells. These deficiencies are accompanied by impaired glucose tolerance, a defect which is moderate when the mice are fed a standard diet (Härndahl et al. 2004). However, in response to HFD the RIP-PDE3B/2 mice exhibit further accentuated morphological derangements; substantial fasting hyperglycemia and glucose intolerance after 2 months on the diet. This is in contrast to wild-type littermates, which apparently successfully compensate the adverse effects of the HFD by increasing insulin secretion and thus display only a mild hyperglycemia, at least until 4-5 months of HFD feeding. Hence, islet dysfunction develops more rapidly and readily in RIP-PDE3B/2 mice. This would suggest that accurate cAMP regulation is important as a protective mechanism for the development of islet dysfunction following HFD feeding.

Data from two long-term studies on HFD-fed RIP-PDE3B/2 mice are presented in this work, the major differences being the age at which the mice were introduced to the diets, and the length of the studies. The majority of the results from the two studies are in good agreement; in the few cases where there are significant differences we consider them to be age-related. For example, because the studies differed in length, mice in 


\section{Insulin / glucagon $\quad$ GLUT2 PDX-1}

Wt CD

RIP-PDE3B/2 CD

Wt HFD
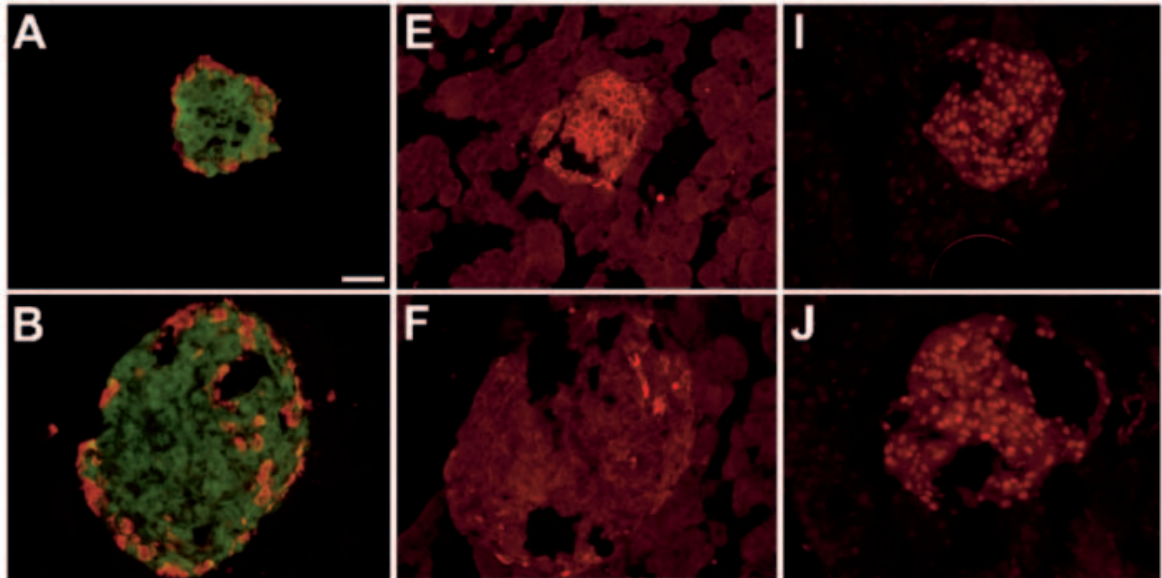

$\mathbf{J}$
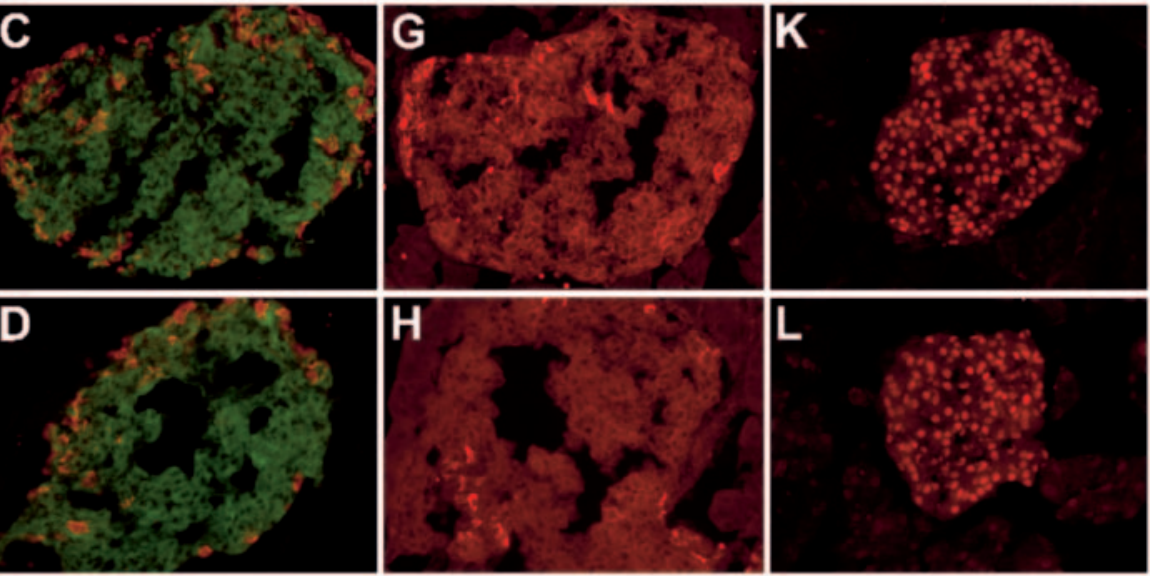

RIP-PDE3B/2 HFD
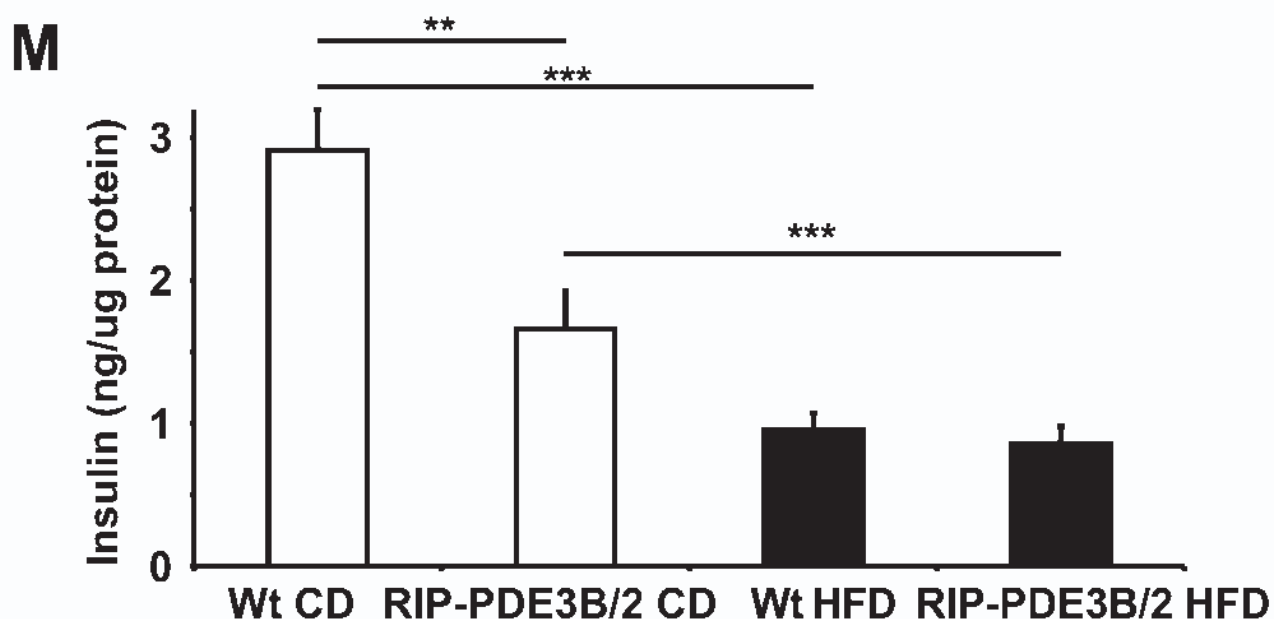

Figure 7 Immunofluorescence of insulin/glucagon, GLUT2 and PDX-1 (A-L) and insulin content (M) in islets from RIP-PDE3B/2 and wild-type (Wt) mice fed either CD or HFD (study I). (A-L) Pancreases were isolated from mice after 18 weeks of dietary treatment and stained for insulin (green)/glucagon (red) (A-D), GLUT2 (E-H) and PDX-1 (I-L). Bar=20 MM. (M) Insulin content measured in groups of three islets in eight replicates. Values are presented as means \pm S.E.M. $(n=8),{ }^{*} P<0 \cdot 05,{ }^{*} P<0 \cdot 01$ and ${ }^{* * *} P<0 \cdot 001$ (ANOVA). Representative images are shown. 
study I were 5.5 months old, whereas in study II the mice were 9 months old when end-point analyses (tissue experiments in vitro) were conducted.

A puzzling finding in the studies presented here is the rapid development of insulin resistance in RIP-PDE3B/2 mice fed a HFD. This was evident by more advanced hyperinsulinemia and early development of hyperglycemia, in spite of hyperinsulinemia, as well as impaired capacity of insulin to suppress plasma glucose in an ITT. We attempted to localize the site of the insulin resistance in HFD-fed RIP-PDE3B/2 mice by in vitro analyses of insulin-stimulated processes in the insulin-sensitive adipose and skeletal muscle tissues as well as the lipid status of the liver. Steatosis of the liver is associated with hepatic insulin resistance (den Boer et al. 2004) and resultant decreased ability of insulin to suppress hepatic glucose production. Our data show that the insulin resistance cannot be readily explained by decreased insulinstimulated glucose uptake in skeletal muscle or reduced insulin-stimulated lipogenesis in adipose tissue. However, the significantly increased accumulation of triacylglycerols found in the liver of HFD-fed RIP-PDE3B/2 mice indicate alterations in the liver that could be associated with insulin resistance. Intriguingly, we also show that CD-fed RIP-PDE3B/2 mice exhibit extensive triacylglycerol accumulation in the liver. It was not possible to detect systemic effects of the fatty livers on glucose homeostasis in the ITT, suggesting that CD-fed RIP-PDE3B/2 mice are able to sufficiently compensate their defects. Future investigations will be necessary to disclose the mechanisms behind the development of fatty livers in these mice and exactly how the effects are compensated.

Obesity and dysregulation of fatty acid metabolism are well-recognized factors contributing to the development of insulin resistance (Bergman \& Ader 2000). In the present investigation, as expected, HFD feeding rendered the mice obese and no difference in fat tissue mass was seen between wild-type and RIP-PDE3B/2 mice. Accordingly, fasting serum FFA levels are similar in mice of both genotypes, indicating that although increases in FFAs may be detrimental for insulin secretory performance and hence for difficulties in maintaining glucose homeostasis in HFD-fed mice, this appears not to be the discriminating factor between RIP-PDE3B/2 and wildtype animals. However, it is possible that the increased level of FFAs in combination with the $\beta$-cell defect becomes a discriminating factor with regard to $\beta$-cell function. Although increased levels of FFAs most likely induce alterations in gene expression and activities of enzymes in $\beta$-cells of wild-type as well as RIP-PDE3B/2 mice, these alterations might synergize with the $\beta$-cell defect, leading to a more severe secretory dysfunction and more severe glucose intolerance in RIP-PDE3B/2 mice. Our in vitro studies support this idea; islets from RIP-PDE3B/2 mice exhibit impaired glucose-stimulated and GLP-1-potentiated insulin secretion and this genotype-induced impairment is more pronounced in islets from mice fed a HFD.

The glucose intolerance observed in the RIP-PDE3B/2 mice could also cause a more severe glucolipotoxicity, leading to more severe insulin resistance. Indeed, it has been suggested that the toxic effect of FFAs on various tissues will become particularly apparent in the presence of hyperglycemia (El-Assaad et al. 2003). Thus the more severe and more rapid development of insulin resistance in RIP-PDE3B/2 mice on HFD could be explained by a combined action of hyperglycemia and elevated levels of FFAs.

Other factors subjected to change in obesity are adipokines, for example leptin. Leptin levels have been shown to increase with insulin resistance (Hotta et al. 2000). In our study, concomitant with increasing adiposity during HFD feeding, hyperleptinemia is seen in mice of both genotypes, although it appears earlier in the RIP-PDE3B/2 mice. In addition, fasting plasma glucagon is elevated in RIP-PDE3B/2 mice, showing a 2 -fold increase over wild-type values already by the start of the study. Plasma glucagon then increases with both age and HFD feeding. As with leptin, though, the increase is evident earlier in HFD-fed RIP-PDE3B/2 mice than in any other experimental group. Elevated glucagon levels are often found in association with type 2 diabetes and are at least partially accountable for increased hepatic glucose production in type 2 diabetes (Shah et al. 2000, Ahrén \& Larsson 2001). It is possible that the early observed hyperglucagonemia, and in turn hyperglycemia, in RIP-PDE3B/2 mice is related to the disrupted islet structure and dislocation of $\alpha$-cells seen in end-point morphologic examinations. Deranged structure and centrally located $\alpha$-cells in pancreatic islets are alterations often seen in type 2 diabetes (Yoon et al. 2003, Deng et al. 2004).

An observation in this study is that HFD-fed RIP-PDE3B/2 mice gain more weight and eat more than HFD-fed wild-type mice. Since the difference in weight gain proved not to be a result of increased adipose tissue mass as such it is more likely attributable to alterations in feeding behaviour. Although it is expected that expression driven by the rat insulin promoter is specific for pancreatic $\beta$-cells the hypothalamic neurons could be a site of contributory action (Cushman et al. 2000) with possible secondary effects on insulin resistance and food intake. However, we have previously examined the RIP-PDE3B mice for PDE3B expression and activity in the hypothalamus and in tissues of interest for metabolism and shown that the increase in PDE3B expression and activity is limited to the islets (Härndahl et al. 2002). It is therefore not likely, although it cannot be entirely excluded, that the aggravated effects on glucose homeostasis and feeding behaviour, compared with equally treated wild-type mice, have primary sources other than the $\beta$-cells.

In summary, these data reinforce the importance of accurate cAMP signaling in pancreatic $\beta$-cells. We show 
that a small increase in the expression of a single PDE isoform, introducing a modest perturbation of the regulation of cAMP, results in substantially increased sensitivity to the adverse effects of a HFD. $\beta$-cell cAMP may therefore be a factor preventing islet dysfunction in a perturbed environment. The RIP-PDE3B mouse model should prove useful for further studies of paracrine activities in the endocrine pancreas and the coupling between insulin secretory defects and glucose homeostasis. Accordingly, this study brings to light the interesting prospect of considering $\beta$-cell PDE3B as a pharmacological target for treatment of diabetes based on modulation of cAMP. The successful results of clinical trials regarding GLP-1-based therapy (Ahrén \& Schmitz 2004, Holst \& Deacon 2004) support this view.

\section{Acknowledgements}

We thank Ann-Kristin Holmén-Pålbrink, Lena Kvist, Lilian Bengtsson, Eva Ohlson and Doris Persson for their excellent technical assistance.

\section{Funding}

This work was supported by the Swedish Research Council (grant nos: 3362 for E D, 6834 for B A and 4499 for F Sundler and N W); a Center of Excellence grant from the Juvenile Diabetes Foundation, USA and Knut and Alice Wallenberg Foundation, Sweden; the Swedish Society of Medicine; the Swedish Diabetes Association; the A Påhlsson, M Bergwall, $\AA$ Wiberg, T Zoega and Crafoord Foundations, Sweden and Novo Nordisk Foundation, Denmark. The authors declare that there is no conflict of interest that would prejudice the impartiality of this scientific work.

\section{References}

Ahmad F, Cong LN, Stenson Holst L, Wang LM, Rahn Landström T, Pierce JH, Quon MJ, Degerman E \& Manganiello VC 2000 Cyclic nucleotide phosphodiesterase $3 \mathrm{~B}$ is a downstream target of protein kinase $\mathrm{B}$ and may be involved in regulation of effects of protein kinase B on thymidine incorporation in FDCP2 cells. Journal of Immunology 164 4678-4688.

Ahrén B \& Larsson H 2001 Impaired glucose tolerance (IGT) is associated with reduced insulin-induced suppression of glucagon concentrations. Diabetologia 44 1998-2003.

Ahrén B \& Schmitz O 2004 GLP-1 receptor agonists and DPP-4 inhibitors in the treatment of type 2 diabetes. Hormone and Metabolic Research 36 867-876.

Ahrén B \& Pacini G 2005 Islet adaptation to insulin resistance: mechanisms and implications for intervention. Diabetes, Obesity and Metabolism 7 2-8.

Bergman RN \& Ader M 2000 Free fatty acids and pathogenesis of type 2 diabetes mellitus. Trends in Endocrinology and Metabolism 11 351-356.
Cushman LJ, Burrows HL, Seasholtz AF, Lewandoski M, Muzyczka N \& Camper SA 2000 Cre-mediated recombination in the pituitary gland. Genesis 28 167-174.

den Boer M, Voshol PJ, Kuipers F, Havekes LM \& Romijn JA 2004 Hepatic steatosis: a mediator of the metabolic syndrome. Lessons from animal models. Arteriosclerosis, Thrombosis, and Vascular Biology 24 644-649.

Deng S, Vatamaniuk M, Huang X, Doliba N, Lian MM, Frank A Velidedeoglu E, Desai NM, Koeberlein B, Wolf B et al. 2004 Structural and functional abnormalities in the islets isolated from type 2 diabetic subjects. Diabetes $\mathbf{5 3}$ 624-632.

Ding WQ, Dong M, Ninova D, Holicky EL, Stegall MD \& Miller LJ 2003 Forskolin suppresses insulin gene transcription in islet beta-cells through a protein kinase A-independent pathway. Cellular Signalling 15 27-35.

El-Assaad W, Buteau J, Peyot ML, Nolan C, Roduit R, Hardy S, Joly E, Dbaibo G, Rosenberg L \& Prentki M 2003 Saturated fatty acids synergize with elevated glucose to cause pancreatic beta-cell death. Endocrinology 144 4154-4163.

El-Metwally M, Shafiee-Nick R, Pyne NJ \& Furman BL 1997 The effect of selective phosphodiesterase inhibitors on plasma insulin concentrations and insulin secretion in vitro in the rat. European Journal of Pharmacology 324 227-232.

Francis SH, Turko IV \& Corbin JD 2001 Cyclic nucleotide phosphodiesterases: relating structure and function. Progress in Nucleic Acid Research and Molecular Biology 65 1-52.

Gromada J, Holst JJ \& Rorsman P 1998 Cellular regulation of islet hormone secretion by the incretin hormone glucagon-like peptide 1. European Journal of Physiology 435 583-594.

Han P, Werber J, Surana M, Fleischer N \& Michaeli T 1999 The calcium/calmodulin-dependent phosphodiesterase PDE1C down-regulates glucose-induced insulin secretion. Journal of Biological Chemistry 274 22337-22344.

Härndahl L, Jing XJ, Ivarsson R, Degerman E, Ahrén B, Manganiello VC, Renström E \& Stenson Holst L 2002 Important role of phosphodiesterase $3 \mathrm{~B}$ for the stimulatory action of cAMP on pancreatic beta-cell exocytosis and release of insulin. Journal of Biological Chemistry 277 37446-37455.

Härndahl L, Wierup N, Enerback S, Mulder H, Manganiello VC, Sundler F, Degerman E, Ahrén B \& Stenson Holst L 2004 Beta-cell-targeted overexpression of phosphodiesterase 3B in mice causes impaired insulin secretion, glucose intolerance, and deranged islet morphology. Journal of Biological Chemisty 279 15214-15222.

Holst JJ \& Deacon CF 2004 Glucagon-like peptide 1 and inhibitors of dipeptidyl peptidase IV in the treatment of type 2 diabetes mellitus. Current Opinion in Pharmacology 4 589-596.

Hotta K, Funahashi T, Arita Y, Takahashi M, Matsuda M, Okamoto Y, Iwahashi H, Kuriyama H, Ouchi N, Maeda K et al. 2000 Plasma concentrations of a novel, adipose-specific protein, adiponectin, in type 2 diabetic patients. Arteriosclerosis, Thrombosis, and Vascular Biology 20 1595-1599.

Hui H, Nourparvar A, Zhao X \& Perfetti R 2003 Glucagon-like peptide-1 inhibits apoptosis of insulin-secreting cells via a cyclic $5^{\prime}$-adenosine monophosphate-dependent protein kinase A- and a phosphatidylinositol 3-kinase-dependent pathway. Endocrinology 144 1444-1455.

Ihlemann J, Ploug T, Hellsten Y \& Galbo H 1999 Effect of tension on contraction-induced glucose transport in rat skeletal muscle. American Journal of Physiology Endocrinology and Metabolism 277 E208-E214.

Manganiello VC \& Degerman E 1999 Cyclic nucleotide phosphodiesterases (PDEs): diverse regulators of cyclic nucleotide signals and inviting molecular targets for novel therapeutic agents. Thrombosis and Haemostasis 82 407-411.

Mehats C, Andersen CB, Filopanti M, Jin SL \& Conti M 2002 Cyclic nucleotide phosphodiesterases and their role in endocrine cell signaling. Trends in Endocrinology and Metabolism 13 29-35. 
Moody AJ, Stan MA, Stan M \& Gliemann J 1974 A simple free fat cell bioassay for insulin. Hormone and Metabolic Research 6 12-16.

Nagy TR \& Clair AL 2000 Precision and accuracy of dual-energy X-ray absorptiometry for determining in vivo body composition of mice. Obesity Research 8 392-398.

Ozaki N, Shibasaki T, Kashima Y, Miki T, Takahashi K, Ueno H, Sunaga Y, Yano H, Matsuura Y, Iwanaga T et al. 2000 cAMP-GEFII is a direct target of cAMP in regulated exocytosis. Nature Cell Biology 2 805-811.

Parker JC, Van Volkenburg MA, Ketchum RJ, Brayman KL \& Andrews KM 1995 Cyclic AMP phosphodiesterases of human and rat islets of Langerhans: contributions of types III and IV to the modulation of insulin secretion. Biochemical and Biophysical Research Communications 217 916-923.

Parker JC, VanVolkenburg MA, Nardone NA, Hargrove DM \& Andrews KM 1997 Modulation of insulin secretion and glycemia by selective inhibition of cyclic AMP phosphodiesterase III. Biochemical and Biophysical Research Communications 236 665-669.

Renström E, Eliasson L \& Rorsman P 1997 Protein kinase A-dependent and -independent stimulation of exocytosis by cAMP in mouse pancreatic B-cells. Journal of Physiology 502 105-118.

Seppala-Lindroos A, Vehkavaara S, Hakkinen A-M, Goto T, Westerbacka J, Sovijarvi A, Halavaara J \& Yki-Jarvinen H 2002 Fat accumulation in the liver is associated with defects in insulin suppression of glucose production and serum free fatty acids independent of obesity in normal men. Journal of Clinical Endocrinology \& Metabolism 87 3023-3028.

Shafiee-Nick R, Pyne NJ \& Furman BL 1995 Effects of type-selective phosphodiesterase inhibitors on glucose-induced insulin secretion and islet phosphodiesterase activity. British Journal of Pharmacology 115 1486-1492.
Shah P, Vella A, Basu A, Basu R, Schwenk WF \& Rizza RA 2000 Lack of suppression of glucagon contributes to postprandial hyperglycemia in subjects with type 2 diabetes mellitus. Journal of Clinical Endocrinolology \& Metabolism 85 4053-4059.

Shakur Y, Takeda K, Kenan Y, Yu ZX, Rena G, Brandt D, Houslay MD, Degerman E, Ferrans VJ \& Manganiello VC 2000 Membrane localization of cyclic nucleotide phosphodiesterase 3 (PDE3). Two N-terminal domains are required for the efficient targeting to, and association of, PDE3 with endoplasmic reticulum. Journal of Biological Chemistry 275 38749-38761.

Skoglund G, Hussain MA \& Holz GG 2000 Glucagon-like peptide 1 stimulates insulin gene promoter activity by protein kinase A-independent activation of the rat insulin I gene cAMP response element. Diabetes 49 1156-1164.

Trumper A, Trumper K, Trusheim H, Arnold R, Goke B \& Horsch D 2001 Glucose-dependent insulinotropic polypeptide is a growth factor for beta (INS-1) cells by pleiotropic signaling. Molecular Endocrinology 15 1559-1570.

Winzell MS \& Ahrén B 2004 The high-fat diet-fed mouse: a model for studying mechanisms and treatment of impaired glucose tolerance and type 2 diabetes. Diabetes 53 (Suppl 3) S215-S219.

Yoon KH, Ko SH, Cho JH, Lee JM, Ahn YB, Song KH, Yoo SJ, Kang MI, Cha BY, Lee KW et al. 2003 Selective beta-cell loss and alpha-cell expansion in patients with type 2 diabetes mellitus in Korea. Journal of Clininical Endocrinology \& Metabolism 88 2300-2308.

Received in final form 24 January 2006

Accepted 10 February 2006

Made available online as an

Accepted Preprint 13 February 2006 